\title{
School Plant Development and Managements A Panacea for Self Reliance and Economic
}

\author{
Paul Nwakpa \\ Department of Educational Foundations \\ Faculty of Education, Ebonyi State University \\ Abakaliki, Nigeria \\ Email: bropaulnwaoo [AT] gmail.com
}

\begin{abstract}
Secondary school education in Nigeria has been saddled with the responsibility of graduating students who can be self employed. The purpose of this noble assignment is to develop and inculcate proper values for survival of individual and the nation; develop intellectual and creative skills for self reliance as well curb insecurity amongst the youths. This paper stressed the need to renew secondary school curriculum to accommodate school plant development and maintenance for self reliance amongst secondary school graduates, it suggested that self reliance will curb youth restiveness thereby enhancing the economic development of the nation. The need for self reliant, youth restiveness and school plant development is discussed. The paper concludes by inferring that poverty can be alleviated, youth delinquency curbed, unemployment reduced, economic status enhanced, if graduates of secondary institutions in Nigeria are equipped with skills with which to be self-reliant.
\end{abstract}

\section{BACKGROUND}

The overall economic performance in Nigeria since independence has been rather unimpressive despite the availability of the huge oil resources. The available records from the National Bureau of Statistics (2006) showed that about 54 percent of Nigerian households lived on less than one dollar a day. However this figure increased to 71.2 percent in (2008) with its growth rate remaining quite feeble especially in the first half of the 1980s when the collapse of the crude oil triggered acute economic crisis in Nigeria. This weak economic crisis according to Tadoro (1987) has resulted in high rate of poverty, low capita per income, high rate of unemployment, youth delinquent etc. all due to government and the masses over depending on the oil sector. An aged long adage says 'catch them young', while the Holy Book also says 'train up a child in the way he should go, and when he grows, he will not depart from it, 'these simply confirm the fact that "as one lays his bed so will he lie on it".

The youths are the leaders of tomorrow; the virtue instilled in them today will determine the kind of society and economy Nigeria will have in tomorrow. Secondary schools house the youths and as such is a very crucial phase in the education sector of the nation. To Thomas (2010), it serves as a "hatchery" for the youth. It is also a determining phase of the nation's positive or negative growth because as a bridge between the primary education and the secondary system, it serves as a consolidating ground for developing either positive or negative vices in the youth, Every society at this stage tries to educate its young members in the way of the society with the aim to produce highly skilled, knowledgeable and independent members who are concerned not only with personal survival but also with the progress of the nation. This stage houses students within the ages of eleven to eighteen years and according to the Federal Government of Nigeria (FGN 2013), the goals of secondary education include preparing a child for useful living within the society and higher education.

This stage in the life of a child needs very tactful planning because this is the decisive stage of a child's life. A stage aimed at raising a generation who can think for themselves, respect the views and feelings of others, respect the dignity of labour, and live as responsible citizens. Has this aim been achieved?

The labour market is changing more rapidly than the secondary school curriculum. The curriculum should be diversified to cater for the differences in talents, opportunities and roles possessed by and open to students after their secondary school course as specified in the overall objectives in the National Policy on Education. This objective stresses on equipping students to live effectively in our modern age of insufficient "white collar jobs". For this reason, students should be encouraged to acquire skills that will make them self reliant after the secondary school education especially those who cannot afford the tertiary education. To achieve this purpose, school plant development and maintenance should be an integral part in the secondary school curriculum not only to enhance the aesthetics of the school but also to help students advance this skill to the larger society.

In our contemporary society, emphasis is so much placed on environmental sanitation. Every city, town and villages emphasize on clean and green environment not only for aesthetics but also for healthy living. To achieve this objective, the Third National Plan in the National Policy on Education recommends $70 \%$ of pupils transiting from primary to secondary schools be sent to vocational and craft schools to acquire these skills. A vocation according to Hornby (2010) is 'a way of life that you believe is especially suitable for you; a calling', while 'craft refers to an activity involving a 
Special skill at making-things with your hand". This implies that some students perform better in vocational and craft than in humanities (grammar school) because craft and vocational studies are more practical than humanities. Besides, vocational and craft education are what they are born to inherit from their forebears through indigenous education.

The above goals as enunciated by the NPE are laudable. However, the question that arises at this point is "To what extent have the beneficiaries of secondary education acquired the craft and vocational skills? How developed is the school plant? To what extent are they involved in the maintenance of the school plant which will enable them to be self-reliant and useful members of the society?" It is the belief of many that the Nigerian economy, are grossly underdeveloped, because the country's basic levels of educational system (primary and secondary) are not equipping the beneficiaries with the needed skills necessary for self reliance, hence economic development. It is not an assumption that the economic development of any country depends on the quality of skills offered by the school system to the citizens of that nation. Secondary schools curriculum developers and administrators should not only include school plant development and maintenance as a core subject in the curriculum but should enforce its practice amongst the students be it grammar or vocational school, and the students should be encouraged to not only offer but partake wholeheartedly in aesthetically maintaining their learning environment and seeing it as a skill which will help them to live a useful life within the society not to see it as menial.

\section{TRADITIONAL EDUCATION AND SELF RELIANCE}

Traditionally, education had existed in Africa right from time before the advent of the Western education. They had their own systems for training their young before the introduction of the western -type education. This training was called indigenous or traditional education because it was part and parcel of the society. To Bamisaye (2002), it was the main, basic and dependable means of livelihood. It enabled the child to develop his abilities, talents and attitudes and other forms of behavior which were of positive, value to the society in which he lived and still assisted the family and the society at large. The boys for example accompanied their fathers to farm, hunting expeditions, mending the family houses, while the girls accompanied their mothers to the farms, and market to buy and sell and help to cook all to bring in money and add value to their lives. But with the advent of the Western education, most of these values were seen to be inferior. A graduate from vocational school where craft and vocation is being taught, which of course is an improvement of the indigenous education and a reflection of our culture, is regarded as inferior to a graduate from grammar school. This is because the child is being brainwashed by the western type of education which dwelt mostly on rhetoric's to the detriment of the vocation and craft which would have been an improvement on the traditional education, which also would have encouraged the student to be self reliant after their secondary education, instead of graduating to wait for 'white collar jobs' that may not come.

Many eminent scholars had expressed dissatisfaction with the system of education provided to Nigerians by the British colonial masters. After the independence in 1960, Nigerians became uncomfortable with the western educational system and started criticizing it. Some of their criticisms according to Nwagwu (2003) included:

(1) The system laid emphasis on academic subjects.

(2) The British trans-imposed the grammar school system of education on Nigeria without due consideration to the culture, environment, labour market, needs and aspiration of Nigeria as a country. As rightly put by a one -time Federal Commissioner of Education, Chief A. Y. Eke,

"No doubt that the educational system we inherited was a good one. Good, that is for the country and society for which it was planned, good for England and English society. But it was not good for us, because it neglected to take into consideration our cultural and social background, because it has tended to produce an educated class of pen-pushers and because it failed to lay the foundation of economic freedom by providing the manual skills and expertise necessary for successful industrial and agricultural development" (Adamu 2005:45).

These criticisms and lapses resulted in the 1969 National Conference on Curriculum Development (NCCD) and subsequently the National Policy on Education (NPE) in 1977 to fashion out the philosophy of Nigeria's education that will respond to the needs and aspirations of Nigerians. A philosophy according to Nwangwu (2003) that will propel the nation to achieving one of its five national goals of being a united strong and self reliant nation with the principle of developing an individual into a sound and effective citizen, not citizens that wait only for white collar jobs after the secondary school education. In order to make the philosophy of education to work harmoniously with the nations national goals, education has to be tailored towards self realization and efficiency amidst other goals. Thus the government declaration on the positive role education can play in nation's economy, as evidenced in the NPE:

...education shall continue to be highly rated in the national development plans because education is the most important instrument of change; any fundamental change in the intellectual and social outlook of any society has to be preceded by educational revolution (NPE, 2013).

Most secondary school graduates are still not self- reliant despite government emphasis on education. Why then did they go to school? The two famous psychologists Abraham Maslow and Carl Rogers in propounding the Humanistic theory of Hierarchy of Needs tried to explain the mechanism of learning by concentrating on the problem 
of why and how people learn? They argued that needs determine the perception of learning. One feels the need of learning or striving because he needs to satisfy his needs. He needs to actualize in life by using and expressing his talents, capacities and potentialities for self development. Anything short of these, result in recalcitrant behavior which is synonymous to restiveness and frustration amongst the secondary school graduates in Nigeria.

\section{SELF-RELIANCE}

Self-reliance, according to Lawrence (2012) hinges on the urge for self-preservation through the independent use of available human and material resources to meet individual needs. It entails creating of new cultural and productive environment which will promote pride in primitive work and self discipline. The above philosophy summarizes the essence of establishing the secondary school arm of education. It is expected that secondary education should not only create the awareness of self-reliance in its beneficiaries but also equip them with the necessary tools with which to be self-reliant and become useful members of the society. To Holborn (2002), secondary education is expected to produce citizens who are equipped with the proper values for their participation in the development of the society as well as produced well adjusted individuals capable of overcoming the disadvantages of poverty. These values or traits will enable them to perform certain tasks independently. These traits will confer on them certain degree of confidence and independence as opined by Castaldi (2000).

\section{REVIEWING THE SECONDARY SCHOOL CURRICULUM}

It is important to reiterate that lack of self reliance results in poverty and poverty is an important factor that militates against useful living within the society (FGN 2013). Ehiametalor (2005) in his study revealed that about $70.2 \%$ Nigerians are poor and by implication cannot send their children to school. He further asserted that perhaps only 29.8 percent of families can afford to live with N140 (1 dollar) or above a day. Mohammed (2004) corroborated this fact when he slated that at the current level of the country's population of 126.2 million, this translated into about 89 million people living in abject poverty, thereby making Nigeria with the highest concentration of people living in extreme poverty. The implication is that this group of Nigerians who cannot feed themselves adequately cannot afford to pay the exorbitant school fees in private schools or train themselves in public universities. The socio - economic hardship deprive many qualified but less privileged children of the opportunity to access university education. Some states in Nigeria especially Ebonyi State is practicing free and compulsory education in the primary and secondary level, it is pertinent that the curriculum should be reviewed to lay more emphasis on school plant development and maintenance as this will culminate the mainstay of the youths means of livelihood instead of being idle and resorting to crime.

Self reliance is equated to entrepreneurship studies. To Ille (2001) entrepreneurship studies are aimed at 'improving the living conditions of the people for the society and vice versa. To Ndan (2005), his insight to a developed society is a society that offers important possibilities to the individual to explore and exploit fully their potentials within well-defined rules of conduct. Paul (2005), perceived entrepreneurial education as structured to offer functional education for the youths so as to enable them to be self-employed and self reliant. And also offer them adequate training that will enable them to be creative and innovative in identifying novel business opportunities. As well as provide the youths with enough training and support that will enable them to establish a career or skill that will enable them meet the manpower needs of the society.

The essence of self reliance therefore is to 'improve' human conditions and this has a lot to do with poverty eradication. Nigeria had an estimated population of 135 million in 2005 and the $13^{\text {th }}$ largest oil producer in the world. Nigeria is the second largest economy in Africa with annual GDP of 71 billion. All other things being equal, oil and gas income combined is worth about 50 cents per Nigerian a day (DFID, 2005). The country's proven oil reserve amount to an estimated proven 32 billion barrels, sufficient to last for about 37years at the current rate of production. With the production of 2 million barrels per day, Nigeria is the sixth largest producer in OPEC. Natural gas reserves will last for 110years at current production levels. In spite of this robust endowment in natural and human resources, the level of poverty of Nigerians stands in contrast to the country's vast wealth. The poverty rate increased from $27 \%$ in 1980 to about $70 \%$ by 1996 . By 1999 , it was estimated that more than $70 \%$ of Nigerians lived in poverty. In spite of the efforts of the government to reduce poverty between 2004 and now, more than half of Nigerians are still poor. This can be attributed to too much emphasis on tertiary education and total dependency on oil and less on self reliant, subsequently the concentration on the quest on white collar jobs and oil sector by the youths. With youths being skillful right from secondary schools through proper awareness of the benefits of engaging in the management of the school plant which is equivalent to entrepreneurial studies, craft and vocation, such opportunities could be converted into fighting and eradicating poverty, (Okebukola 2003).

Self reliance helps the student to be self -independence. Independence according to Hornby (2010) means doing things on one's own, depending on one's self, being self-reliant, accepting personal responsibility for task which, under different circumstances one can rightly expect the help of others. Independence helps boost a child's creativity and innovative power which to a large extent eradicates poverty resulting in confidence and traits such as integrity, honesty and ethical strength. As a result of the absence of new sets of values and planning for tomorrow, amongst Nigerians, corruption, deceit, suspicion, ethnic chauvinism have' rendered the pursuit of self-reliance among our youth difficult to attain. 


\section{SCHOOL PLANT}

The importance of the school learning environment can never be overemphasized. The physical environment which comprises of the buildings, classrooms, offices, libraries, laboratories, technical workshops, school halls, recreational park, the lawns etc constitute the school plant. The school is established to serve the society, the society constitutes of people and people accept things that arc of positive value and benefit to them. If the society must benefit from education which-serves as a change agent then the needs, aspirations and desires of such a society must; be protected and this protection stems from the school environment especially the secondary school. Castaldi (2000) asserts that what human beings see, hear and feel, cannot be divorced from their surroundings. His argument is that the environment serves as the background against which all configurations can be identified. The environment determines how and what learners learn. Control and coordination of facilities which enhance learning and subsequently skill acquisition are but very important preliminary steps for being self reliance.

Social relations and reforms are reinforced mostly in the school. Nisbet (2007), viewed it as a unit of solution in society and a process through which people take initiatives and act collectively. That is why to Benson (2002), a school is a relatively small isolated centre with stable population, in which all social services necessary to life, can be maintained. In essence, a school is for the purpose of processing students into productive and employable citizens to service the needs, desires and aspirations of the society.( Peretomode, 2003),. It is believed that 'charity begins at home ${ }^{1}$. Many parents, choose schools for their children based mainly on the general appearance of the school compound from outside. There is a belief that, if the buildings in the school are well maintained and the grounds well kept, the same level of care, seriousness and high quality will also be extended to the academic programmes of the school. Adaralegbe (2002) maintains that the right type of atmosphere required for effective learning is the one consisting of better teaching facilities. Such a learning atmosphere is to be carefully planned by a team of experts, implemented by serious minded professionals and maintained by effective administrators. This calls for school plant management. To Mbikpom (2000), to provide a favourable environment for learning, the school grounds and plant must be properly managed.

In most primary and secondary schools, the pupils and students are expected to cut the grass, plant and tend the flowers and orchards alongside government employed labourers for government owned schools and daily paid for privately owned schools. This implies that the student must be exposed to the planting of flowers, mowing of the lawns, picking and disposing of waste properly and adequately maintaining the overall sanitary of the school within and outside the premises, not as a punitive measure but should be made to see it as a part of skill acquisition which if properly executed will help sustain them in future. With this awareness, they will learn the art of landscaping and refuse management; an art and skill if well cultivated can enhance the financial status of the students thus helping the child to be self reliance or be gainfully employed.

The school plant must act as a nursery for the student. A nursery according to Hornby (2010) is a place where young plants and trees are grown for sale or for planting somewhere else. Likewise, schools should justify their functions of processing students into all round responsible, cultured and matured citizen, one that should be ready to serve his fatherland in any capacity he deems fit. They should inculcate in them the dignity for labour. Students are multi-talented therefore the school should be able to cater for the differences in the student's talent so that they will be able to fulfill the roles expected of them after secondary school education. They should be able to equip students to live effectively in our modern age of science and technology, develop and project Nigerian culture, art, language and cultural heritage. An educational institution should be able to instill in the students the need for social change to meet with global standards.

Maslow in Morokola (2003) postulation of the five basic needs being the physiological needs, the safety needs, the social needs, ego or esteem and the self-actualization needs, all point to the need for a child to be independent, be self reliance and independent of government white collar job which is highly saturated and in very high demands. For a child to be esteemed means a child should not be relevant to himself alone, but his family, his community and the world at large by contributing his own quota to the growth of his community. If the school being a formal learning environment, can live up to its expectations, then the students will be confident of being self employed after graduating, this will arrest the psychological effect of frustration due to joblessness and total dependence on white collar job. Schools are supposed to be a centre of excellence, a place where a child's mental health will be enhanced. The mental health is very vital for the life and well being of an individual. People's health involves their emotional, social and physical well being and this is greatly determined mostly by the economic context of their lives. A school is also supposed to help in developing a child's talent, according to Benson (2002) 'one of the most important ideas of education is compressed into the Platonic lines: 'what is honored in a country will be cultivated there'. A talented child is one who is naturally endowed. A student who is artistic will want to exhibit his talents in various ways and one of such ways is by aesthetically enhancing the school environment A child from an aesthetically enhanced school environment is bound to perform excellently better and attract good friendship than a student from an "ill-health" or "sick" or "filthy" environment. He will feel needed, loved, esteemed and have that sense of belongingness. He will feel confident resulting in competence thereby boosting his ego and status. He will not feel inferior to his mates because he sees himself as competent and able as rightly put by Benson, He will want to practice what he learnt in school through school plant development and maintenance. 
School plant development and management will also result in the fulfillment of the students esteem need which will lead to feelings of self- worth, adequacy and self-confidence. The inability of the principals to maintain the school grounds may result in the student feeling discouraged and inferior to other students from other beautifully landscaped school or a school whose students dressed code is corporate and this will affect the student even after the secondary school education, he will inferior to his mates from an enhanced school environment.

\section{INFRASTRUCTURES}

Educational institutions require more and better facilities to enhance academic excellence. In most secondary schools, there is lack of health facilities, bad sanitary conditions and practices, 'bad system of waste disposal and lack of water supplies. Health clinics should be introduced in schools and students should be involved in managing health crisis in schools as well as provide first aid treatment to students involved in minor crisis. Health personnel and medical experts alongside the students should educate the students and members of staff on other health related concerns as HIV/AIDS, sexually transmitted Disease (STD), cancer, tuberculosis etc. This will act as a spring board to a child choice of community health worker after graduating. All these vices will definitely influence the student's altitude towards practicing the school plant maintenance skill after school,

\section{YOUTH DELINQUENCY/ATTITUDINAL CHANGE}

One of the key concepts in psychology is learning. Learning is a continuous process of interaction between the individual and certain elements, events or conditions within the environment of his birth, training or activity. These events or conditions in the environment, elicit some responses from the individual, which in turn shape, modify or change him in a special way, to enable him function positively in whatever situation he finds himself. Okoro (2002) defines learning as 'a relatively permanent change in behavior potentials that occur as a result of reinforced practice'. It is not limited to a mere change in behavior. It also includes the process of acquiring skills or knowledge and the functional application of what has been acquired. Oduaran (2000) sees learning as a process of acquiring knowledge, skills and attitude through experiences and applying same to his daily functioning.

Ejide (2002) observed that 'changes in behavior must be evidenced in individual's performance, training and experience, which must be influenced, enhanced or affected by prevailing events, episodes, objects, or conditions, within the learner's environment". These enhancers, or drives within the training/ learning situation including personnel, school plants, lawns, facilities, buildings and general aesthetics -act as nourishment and support pillars for the social transformation of the individual". A child according to Bulus (2002) is a product of his environment, and the environment is rapidly changing from serenity to violence and crime, from peace to terrorism, from friendliness to enmity, from calm to turbulence; why? One of the likely answers to this negative trend is idleness among the teeming youths. Youths are waiting for government employ; otherwise referred to as 'white collar jobs'.

An aged long adage has it that "an idle mind is the devil's workshop". In Nigeria, any criminal act committed by a youth is to be considered as a delinquent act. Idleness is a social order which has turned most youths into delinquents. Delinquency as reported by Voorhes (2000), West (2001), and Yates (2002) connotes an act or behavior which violates a norm or a rule in a particular community. Idleness can make a child to be emotionally erratic, unstable and highly sensitive to tensions in the family and in the community at large. Idle youths are found to be more aggressive, suspicious, jealous, hostile, destructive, impulsive with very little self control, defiant to authority and over assertive when compared to their males who are gainfully occupied (working or in tertiary institutions).

The anti-social act of delinquents ranges from 'offences against persons to offences against properties. Reasons for this delinquent behavior according to Savason (2000) are the following: The breakthrough of aggressive impulses, rebellion, feelings of low esteem, reaction against depression, thrill seeking, deprivation, crowd behavior and peer group influence. The school is a formal learning environment and any environment in which an individual finds himself in time and place affects the way he learns and subsequently behaves. The important rider here is that the school environment is an important determinant in human development. The particular environment in which an individual finds him/ herself and responses to it at a given time, by and large, makes or mars the child's abilities, capabilities or potentialities (Denga,2002). A defective environment, resulting from poor planning and or poor maintenance, is an impediment to good citizenship, individual excellence and full development of the potentials of the individual (Lawrence 2012). On the contrary, a rich and enriching environment helps the inherited potentialities to mature and function (Denga,2002). This means that the inherited potentialities are worthwhile variables, which enhance learning and skill acquisition.

School plant development should not only require learning and physical aesthetics but should also help change attitudes of the students. Attitude according to Hornby (2010) is "the way one thinks and feels about something/somebody, also defined as confidence, sometimes aggressive behavior towards something ${ }^{1}$. School plant management in this instance is seen as "enactment of values (Mbikpom 2000). This means that the development of a school community is also tied to the nature and characteristics of its individuals. However, in most school communities, especially the public schools, most students come from low income homes (poor background) that cares less about caring and respecting aesthetics at home, they do not appreciate the school plants, they cross the 
lawns, pick flowers at random, not friendly to school properties, destroy the properties at will, abuse the school compound with litters. They do not observe the school rules of thrashing waste products at designated can, pose bills unnecessarily. They are not values oriented and lack of this value identification by the students will distort school plant developmental efforts. When this happens, such schools find it difficult to define, deliberate, calculate, determine and prioritize their values in terms of preference. This misplacement of priorities often leads to suspension, slow-pace, or outright abandonment and termination of school plant development, and sustainability, (Cox 2000). The culture of respecting, valuing and maintenance of school plant should be made compulsory by including school plant maintenance as a compulsory subject in the school curriculum, because a student that respect the school plant is bound to be a patriotic citizen and will love to acquire school plant development and management as a skill towards self reliance.

\section{CONCLUSION}

Self reliance through school plant development and management is the focus of this paper. Section 6, (49) of the National Policy on Education (Technical Education) is to provide people who can apply scientific knowledge to the environmental and solution of environmental problems for the use and convenience of man as well as give training and impact the necessary skills leading to the production of craft men, technicians and other skilled personnel who will be enterprising and self-reliant etc. To this end, school plant development and maintenance which involves landscaping and health management is a craft that can lead to one being self reliant thus averting crime, terrorism and indeed curbing youth restiveness among Nigerian youths. Including it in the school curriculum making it compulsory should not be over-emphasized because this is one of the vital ways of curbing youth restiveness in our society.

\section{RECOMMENDATIONS}

1. Youth delinquent is better prevented than treated. Schools can contribute to its prevention by diversifying the curriculum to be responsive to Individual and societal needs and aspirations, should be responsive in its coverage and adaptable to changing needs, time and conditions.

2. Government and communities should help by creating more avenues for vocational training through school plant development and encourage the youths to be self reliant.

3. Parents also need to listen, guide, supervise and direct their children's behavior toward being self reliant.

4. School administrators should maintain the school plant to attract students so that they may be schooled to desist from delinquent acts and imbibe an entrepreneurial approach to life through school plant development and management.

\section{REFERENCES}

- Adamu, A. U. (2005). Education: Yesterday, Today, Tomorrow. Leadership: October 23, November 6, November 20. Abuja Free Press.

- $\quad$ Adaralegbe, A. (2002). Philosophy of Nigerian Education. Ibadan: Heinetnan.

- Bamisaye, O. (2002), Sociological Foundation of Nigerian Education: An Introduction. Ibadan: A. M. D. Publishers.

- $\quad$ Benson, P. (2002). Guiding Creative Talents. New Jersey: Prentice Hill.

- Bullus, I. (2002). The Learning Environment: A General Conspectus of its Effects on School Performance, in R. U. N. Okonkwo and Rommy O. Okoye (2002) (Ed). The Learning Environment of the Nigerian child. Awka: Erudition Publishers.

- Castaldu B. (1977). Educational Facilities: Planning, Remodeling and Management. Boston: Allen and Bacon Inc.

- Cox, F. (2000). Strategies of Community Organization. New York: Peacock.

- Denga, D. I. (2000). An Introduction to Foundation of Education. Calabar: Rapid Educational Publishers Ltd.

- Ehiametalor, E. T. (2005). Issues of Access and Equity and Private Sector Participation in the Deregulation of Education. In G. O. Akpa? S.U, Udo and E. O. Fagbanmiye (Eds) Deregulating the Provision and Management of Education in Nigeria. Jos: The Nigerian Association for Educational Administrative and Planning (NAEAP).

- Ejide, B. (2002). The Impact of the Environment on the Cognitive Development of the Child in R. U. N. Okonkwo and Rommy O. Okoye (2002). (Ed). The learning environment of the Nigerian child. Awka: Erudition Publishers.

- Fafunwa, A. B. (1974). History of Education in Nigeria. London: George Allen Publishers.

- Holborn, H. I. (2002). Sociology: Themes and Perspective. London: Harper Collins Publishers Ltd.

- Hornby, A. S. (2010). Oxford Advanced Learner's Dictionary of Current English. Oxford: Oxford University Press.

- He, N. M. (2001). Entrepreneurship Development: The Nigerian Perspective. Enugu: Chiezugo Ventures.

- Maslow, A. (1969). A Theory of Meta-Motivation. The Biology of Rooting of the Value-Life. In O. A. Morokola 
(2003). School Health Programme. Ibadan; Royal People Nigeria Ltd.

- Mbikpom, G. (2000). Educational Administration and Planning. Calabar: University of Calabar Press.

- Mohammed, N. S. (1998). "Equality of Educational Opportunities as a Critical Factor in National Development: Problems and Prospects", in Z. Mohammed, E. O. Obi, B. J. Gayus, M. N. Katsina and J. A. Agbo (Eds) (2003) Issues in Political Violence in Nigeria, Katsina: Gombarau Publishers Limited.

- Federal Government of Nigeria (2013). National Policy on Education. (4 ${ }^{\text {th }}$ Edition) Lagos: NERDC.

- Ndan, E. N. (2005). Attitude and Values for Self-Reliance and Progress in a Democratic Setting: Educational Implications in B.B. Oderinde and O.O. Ekpo (eds) Value Education. Lagos: The Nigerian Academy of Education Publishers Limited.

- Nisbet, R. E. (2007). A Question for Community. New York: Oxford University Press.

- Nwangwu, I. O. (2003). Educational Policies in Nigeria: Trends and Implementation. Nsukka: Jobus International Press.

- Oduaran, A. B. (2002). Effective Adult Learning and Teaching. Ibadan: Ibadan University Press.

- Okebukola, P. Sambo, A. Adeogun T. A. Quadri O., Bankole, A. and Popoola, O. O. (2003). Unit Cost of University Education in Nigeria (2001 - 2002). Abuja: NUC.

- Okoro, C. C. (2002). Basic Concepts of Educational Psychology. Nsukka: Academic Publishers Nigeria Ltd.

- Paul. E. O. (2005). Entrepreneurship and Vocational Education. Enugu: OZVBEL Publishers.

- Peretomode V. F. (2003). Educational Administration: Applied Concepts and Theoretical Perspective for Students and Practitioners. Lagos: Joja Educational Research and Publishers Ltd.

- Savasun, J. G. (2000). Abnormal Psychology: The Problem of Maladaptive behaviour.2 ${ }^{\text {nd }}$ ed., Englewood Cliffs. NJ: Prentice Hall.

- Thomas, N. A. (2010). Role Performance of Principals in Akwa Ibom State Secondary Schools, Nigeria. An unpublished Ph.D Dissertation, University of Calabar.

- Todaro, M. (1987), Economic Development in the Third World. New York. Longman

- Todaro, M. (2004). "89 Million Nigerian below Poverty Level, Says Minister of Employment, Labour and Productivity" The Nigerian Guardian, Tuesday7

- Ukeje, B. O. (1985). Education for the Survival of the Nigerian Nation. Port Harcourt: University of Port Harcourt Press.

- Voorhes, J. (2000). Neuropsychological Differences between Juvenile Delinquents and Functional Adolescent: A Preliminary Study, Adolescence. XVI, (61), 57-66. West, D. J. (2001). The Young Offender. New York: International University Press.

- $\quad$ Yates, A. J. (2002). Behaviour Therapy. New York: John Wiley and SMS Inc. 209-217 